\title{
International Trade and Finance Under the Influence of Oil-1974 and Early 1975
}

\author{
HANS H. HELBLING
}

I

$\mathrm{N} A N Y$ given period, a country's economic performance in the international arena is determined by both domestic and foreign forces. In 1974, however, external forces (the operation of a foreign oil cartel) exerted an ovenwhelming influence on virtually all U.S. intemational transactions - both imports and exports.

In addition to the impact of higher oil prices, U.S. international transactions were affected by the depreciation of the U.S. dollar against most major currencies, high, though differing, rates of inflation here and abroad, cyclical downturns in many countries, and the removal of capital controls. Some of these factors are likely to continue to influence our international economic perfomance in 1975 .

At the beginning of 1974 , rates of economic growth in most of the world were declining in response to both supply constraints and earlier measures which had been designed to slow the unsustainable economic expansion which prevailed in 1972 and early 1973. Not the least of these supply constraints was the October 1973 - March 1974 oil embargo and the quadrupling in oil prices. This latter development also caused significant changes in relative prices within oil importing countries and thus influenced their reported rates of inflation.

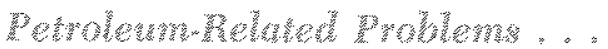

With the announcement of higher oil prices, oil importing countries became concerned about ensuing oil payments and how to finance them. The fear was that onl exporting cotntries would accumulate claims on the output of all oil importers but would invest their oil revenues in only a few industrial countries. Furthermore, there was concern that the financing burden of some countries would be so large as to severely retard their future economic growth. Coin. ciding with the development of these fears was the implementation of an earlier U.S. decision to eliminate existing controls on capital exports. Thus, if U.S. financial markets would experience the anticipated surplus inflow of funds from OPEC (Organization of
Petroleum Exporting Countries), U.S. banks would not be restricted in the intermediation of such funds to other oil importers.

A further oil-related fear was that as a result of projected trade deficits, countries might pursue policies aimed at coping with their own problems while disregarding the possibly adverse effects on other countries - generally referred to as beggar-thy neighbor policies, Thus, while one conntry might beneft in the short run, in the long run all countries would eventually lose if every country pursued such policies, In response to such fears, the countries belonging to the Organization for Economic Cooperation and Development (OECD) reached an agreement in May 1974 to refrain from implementing beggar-thy-neighbor policies.

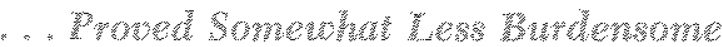

The impact of the oil embargo, however, was not as severe as initially anticipated and there was a change in the pattern of demand for the world's currencies. Some commercial banks, which had incorrectly anticipated exchange rate developments and based their trading of individual currencies on earlier projections, incurred musually large financial losses once their anticipations were not realized. This led to the insolvency of some banks and increased the uncertainty over how oil payments would be financed. However, toward the end of the year, financial markets calmed, partly because the intemational banking community began to understand the true impact and proportions of the oil transfer problem.

Large merchandise trade deficits did emerge in most oil importing countries, as expected, but the burden of oil financing was handled almost entirely by the private financial markets of the world. As a supplement, members of OPEC provided loans to some less developed countries as well as to Britain, France, and Japan. Other intergovermmental financing arrangements, such as the gold-guaranteed loan by Germany to Italy, and the establishment of a special account at the International Monetary Fund (IMF), were undertaken. 


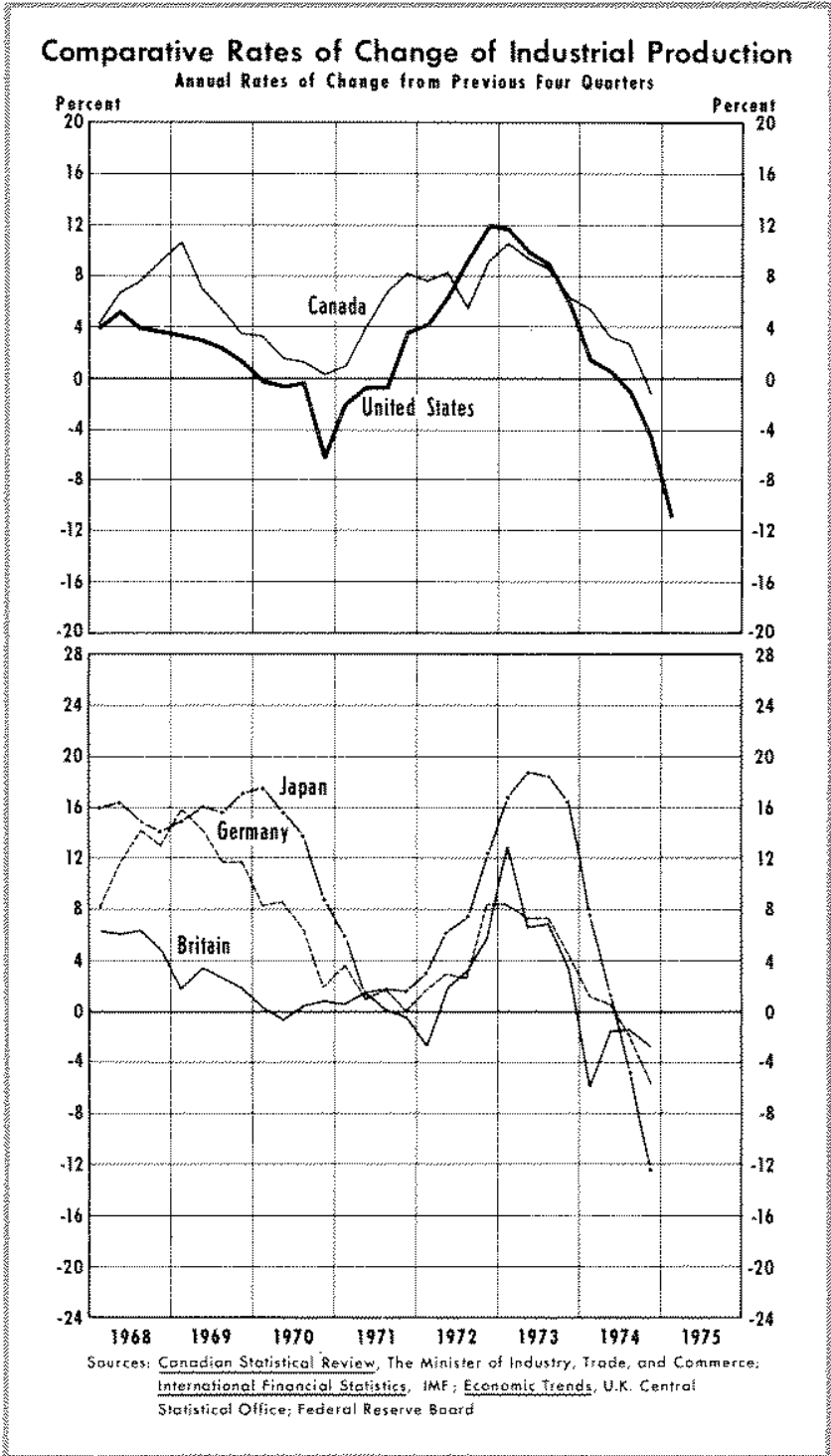

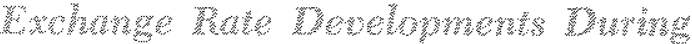

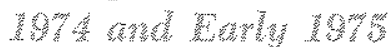

Unusually large capital movements occurred as a result of the oil price increases and the subsequent financing operations. Initially, many analysts both here and abroad believed that the U.S. economy was less vulnerable than other countries to a cutback in imported oil, making dollar denominated assets attractive to foreign buyers. In addition, there was expectation that the increasing receipts of oil exporting countries would be invested mainly in dollar denominated assets. As a consequence, there was a rise in the international price of the dollar early in 1974.

During the second quarter of 1974 , after oil shipments had resumed, the U.S. trade deficit increased faster than initially expected, U.S. output declined more sharply than expected, and inflation accelerated.

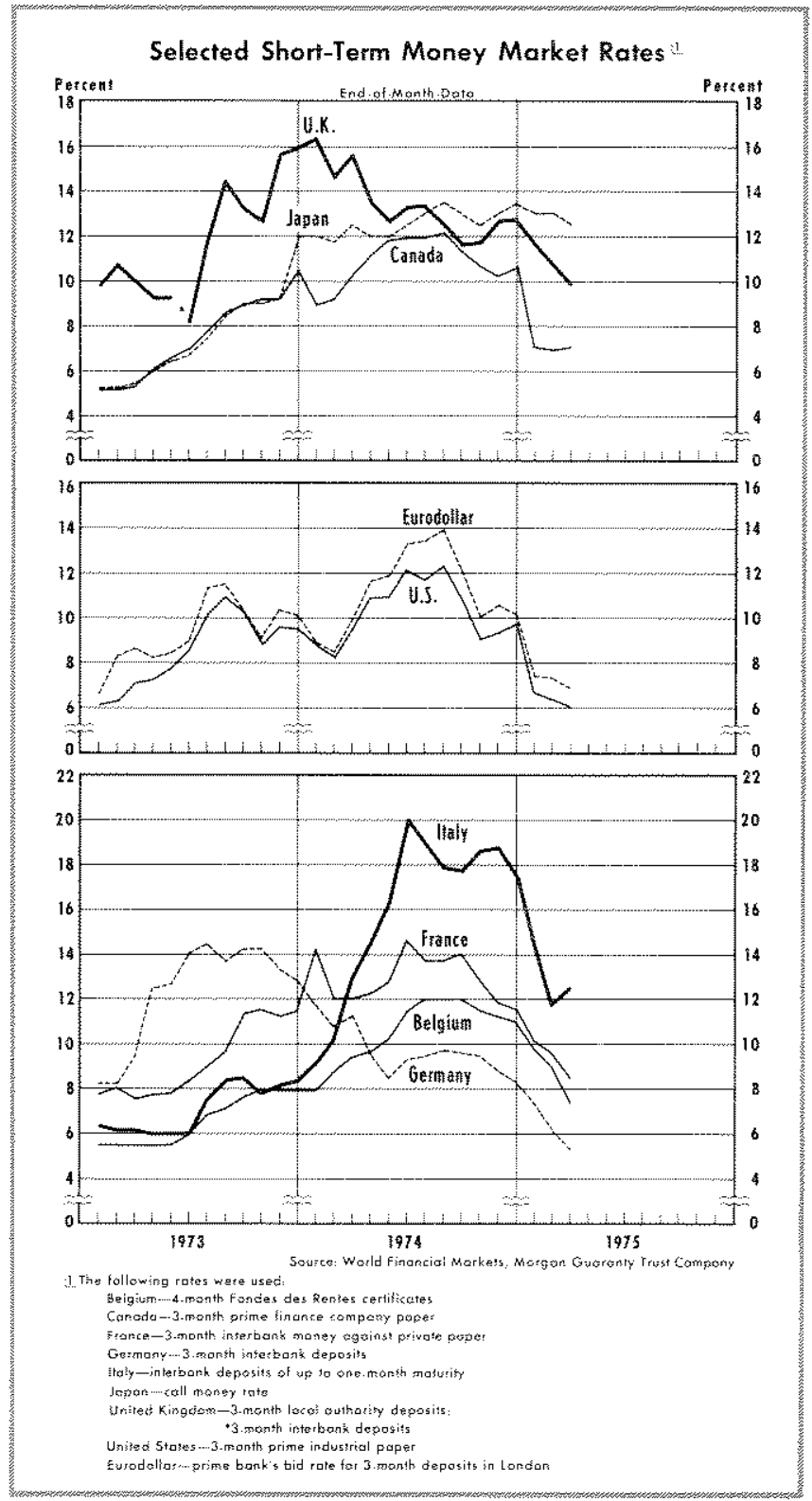

These factors all contributed to a decline in the international price of the dollar after the first quarter rise.

In mid-May 1974, the dollar depreciation halted and began to reverse. Reduced rates of monetary growth, rising interest rates in the United States relative to other countries, and the continuing large accumulation of dollar denominated assets by OPEC in Euromdollar and U.S. financial markets contributed to the renewed strength of the dollar. Beginning in September, however, the international price of the dollar declined again, probably in response to the marked slowdown in U.S. economic activity, declining U.S. interest rates, and reports that OPEC might shift from dollars and sterling into continental European currencies, 


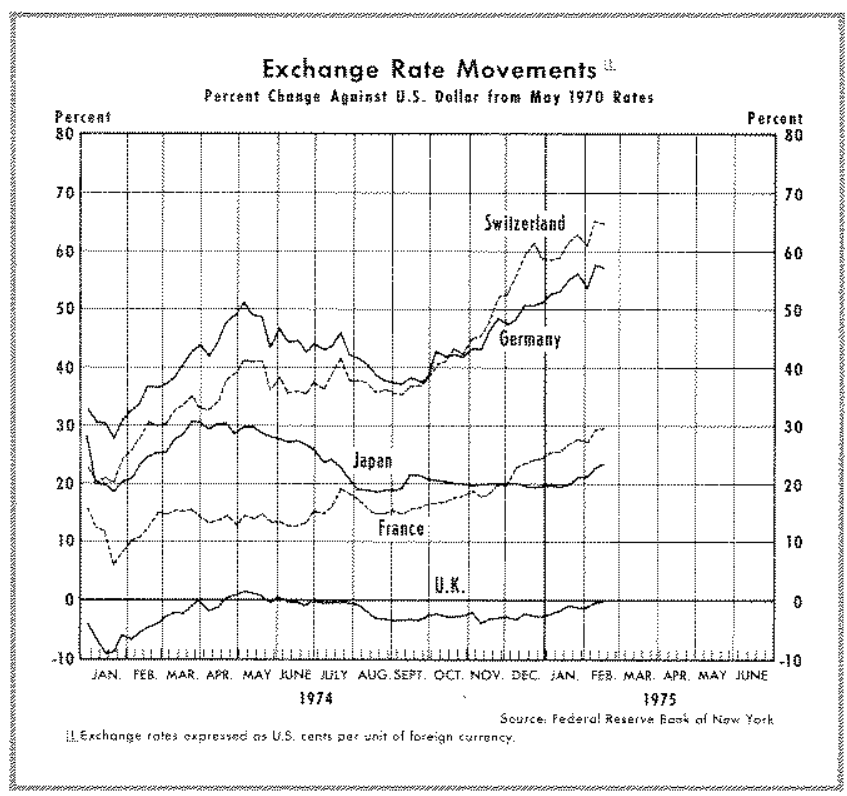

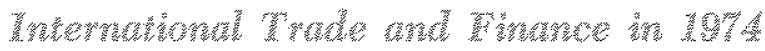

The 1974 merchandise trade performance was greatly affected by the sharply increased oil import prices, despite the fact that oil import volume has declined slightly since 1973 . In fact, if oil imports are excluded from these measurements, exports exceeded imports by $\$ 19.2$ billion in 1974 .

A breakdown of U.S. international trade by countries reveals that while the volume of U.S. imports from oil exporting countries increased, so did exports to those countries. For example, U.S. merchandise imports from OPEC increased from $\$ 5$ billion in 1973 to $\$ 17$ biflion in 1974 . U.S, merchandise exports to OPEC, on the other hand, increased from $\$ 3$ billion in 1973 to $\$ 6$ billion in 1974 .

The dollar value of exports exceeded the dollar value of imports for agricultural products, capital goods, and chemicals in 1974, but the quantity of agricultural exports declined by 9 percent. On the other hand, the dollar value of imports of consumer goods exceeded exports somewhat more than in 1973. On balance, in 1974, merchandise imports exceeded merchandise exports by $\$ 5.8$ billion.

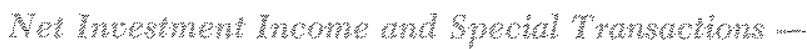
Net investment income increased to $\$ 9.7$ billion in 1974 from $\$ 5.3$ billion in 1973. A large portion of the 1974 increase resulted from inventory profits following oil price increases and receipts from a large volume of U.S. bank loans to customers abroad. There were also special bookkeeping transactions such as the $\$ 2$ billion U.S. Government grant to India which was used to repay previous loans.

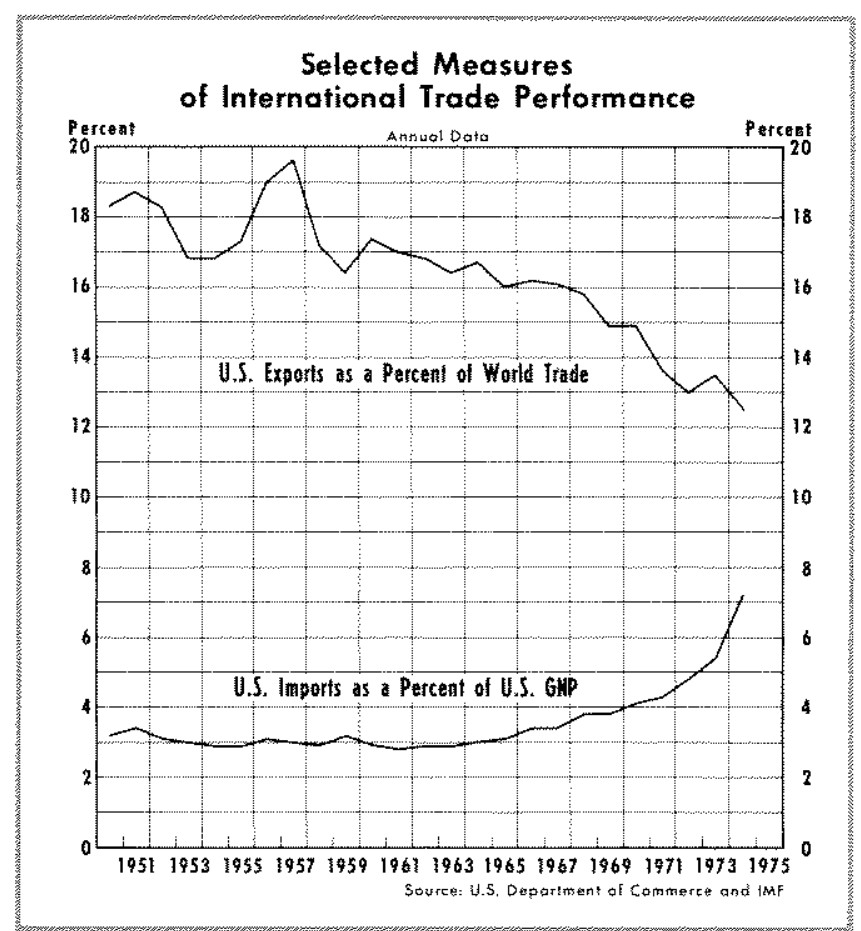

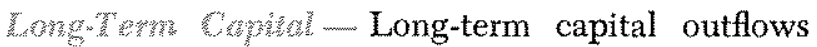
increased significantly in 1974. U.S. direct investment abroad amounted to $\$ 6.8$ billion in 1974 , as compared to the 1973 investment of $\$ 4.9$ billion. At the same time a reduction of foreign purchases of U.S. stocks and bonds significantly reduced inflows of long-term capital. Inflows of foreign capital for direct investment in the United States fell slightly to $\$ 2.3$ billion in 1974, compared to $\$ 2.5$ billion in 1973 .

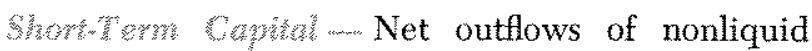
short-term capital, mainly U.S. bank loans to foreigners, increased rapidly during the first half of 1974 . A number of factors contributed to this development: increased loan demand to meet oil import payments, the removal of U.S. controls on capital outflows early in the year, and higher interest rates in many foreign countries relative to those in the United States. During the second half of 1974 , however, U.S. bank loans to foreigners were considerably smaller than in the first half. This may have been related to a narrowing of the differential between U.S. and foreign interest rates and a leveling-off in foreign loan demand as the volume of oil shipments returned to more normal magnitudes following the post-embargo rebuilding of stocks.

It is apparent from this discussion that virtually all major international transactions were influenced by the greatly increased oil import prices. For this reason, a more detailed analysis of the oil situation is presented in the next section. 


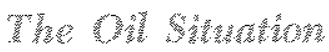

In spite of all the rhetoric about reducing our dependence on foreign sources of oil, during 1974 the United States actually increased the proportion of oil acquired from foreign producers. During 1974 U.S. oil consumption averaged 16.8 million barrels per day (MBD) while domestic production was 11 MBD. Imports amounted to $6.1 \mathrm{MBD}$, or 36 percent of total domestic consumption. ${ }^{1}$ In 1973, for comparison, oil imports amounted to 35 percent of domestic consumption. In order to put this development into perspective, U.S. oil consumption, production, and imports are examined for the period 1950-1974.

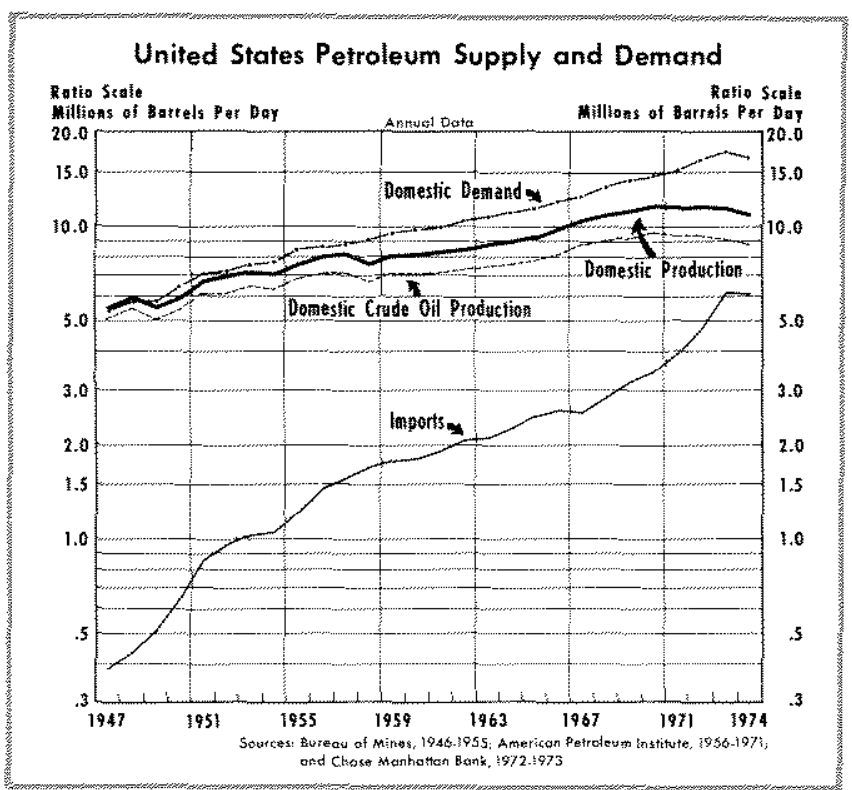

D. Wu cansumpon - In terms of the pattern of U.S. oil consumption, there are four distinct periods between 1950 and 1974, Between 1950 and 1964, U.S. consumption of oil grew at an annual rate of 3.8 percent. From 1964 to 1971 , consumption increased at an annual rate of 4.7 percent and from 1971 to 1973 accelerated to a 7.2 percent annual rate. In response to the oil embargo, sharply higher oil prices, and the economic contraction experienced by the U.S. economy, oil consumption in 1974 decreased at a 3.9 per. cent annual rate.

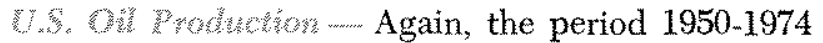
can be divided into four subperiods in terms of oil production. Total production of crude and refined oil in the United States between 1950 and 1964 increased at an average annual rate of 3 percent. From 1964 to 1966 the rate of production briefly accelerated

1The difference between domestic production plus imports and domestic consumption is due to the rebuilding of oil stockpiles. to a 4.6 percent annual rate of increase. Begiming in 1966 and continuing through 1972 , however, the rate of production increased at only a 2.8 percent annual rate. Finally, since 1972 domestic production has declined at a 2.8 percent rate. Thus, from 1966 through 1973, the difference between domestic oil consumption and domestic oil production widened. In 1974 , the differential narrowed as consumption declined more than production.

This state of affairs is partially attributable to the fact that the expansion of oil production facilities was hindered by a number of factors. Among these factors were environmental and safety regulations which hampered attempts to construct new, and expand existing, drilling and refining facilities. General price controls, which affected the oil industry both directly and indirectly, created bottlenecks in the production of materials utilized in the construction of new facilities. In addition, the existing dual price system for oil - different prices for "new" and "old" oil - certainly was not conducive to providing the necessary incentives for increasing production in 1974 .

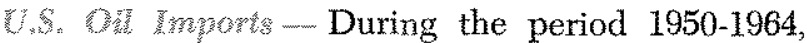
U.S. imports of oil increased at a fairly steady 7.2 percent annual rate. From 1964 to 1967, reflecting the increase in domestic crude oil production, U.S. oil imports slowed to an annual rate of increase of 4 percent. Beginning in 1967, however, U.S, oil imports increased at a very sharp rate. For example, from 1967 to 1970 imports rose at a 10 percent annual rate and between 1970 and 1973 , as a result of absolute declines in domestic oil production, and cyclical increases in economic activity, accelerated to a 22 percent annual rate of increase. Finally, in 1974, oil imports declined 1.7 percent from 1973.

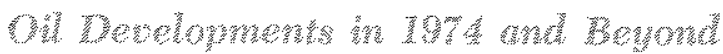

As was expected at the beginning of 1974, gross receipts by OPEC for oil exports amounted to $\$ 90$ billion last year (receipts for other exports amounted to an additional $\$ 5$ billion). However, OPEC expenditures on imports amounted to $\$ 35$ billion, or about onewthird of total receipts.

Net OPEC receipts (total receipts mines expenditures for imports), amounting to $\$ 60$ billion, were disposed of somewhat differently than initially expected. For example, direct placement of OPEC funds in the United States amounted to only $\$ 11$ billion. Placements in the (more anonymous) Eurocurrency market, on the other hand, amounted to $\$ 21$ billion. It is probable, however, that some OPEC Eurocur- 


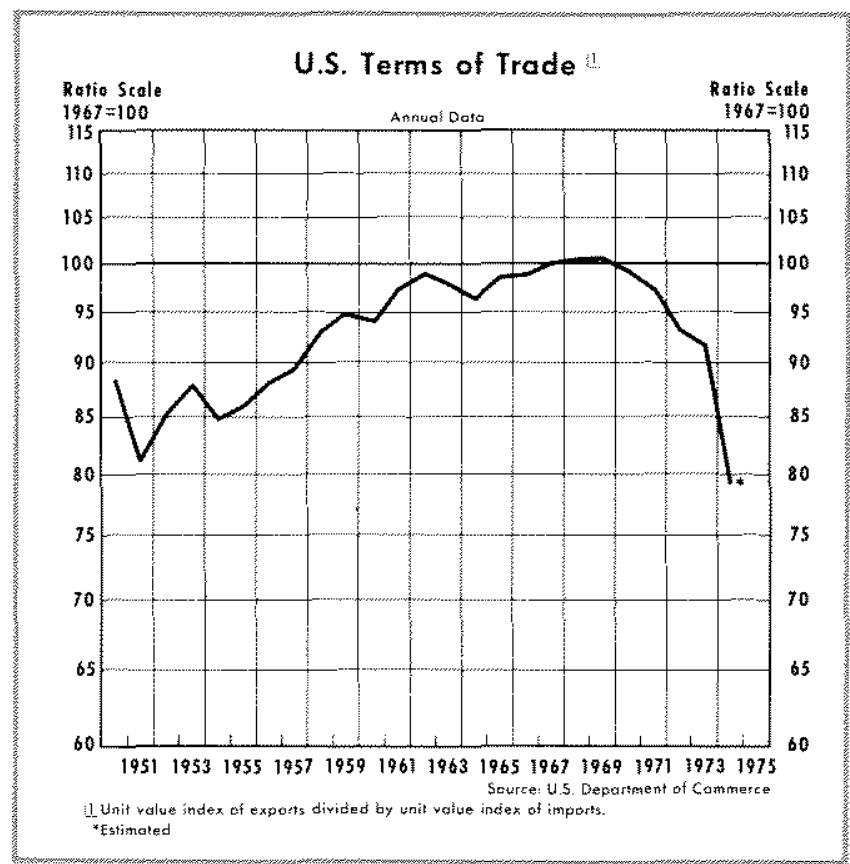

rency placements were eventually channeled to U.S. financial markets also. ${ }^{2}$ The remainder was composed of loans and investments to other countries and to international institutions.

With respect to the absorptive capacity of OPEC countries, it is now apparent that far more oil revenues than had been initially expected will be expended in the near future for the purpose of establishing or improving industries in oil exporting countries. OPEC imports from the United States increased by 90 percent during 1974 and, while such a rate of increase is not sustainable, the level of OPEC imports will surely exceed that of years prior to 1974 .

With respect to the consumption of oll in both the United States and abroad, it seems reasonable at this time to expect little or no growth in the next few years. For one thing, high oil prices and temporary reductions in the growth of aggregate demand, both in the United States and other countries, have reduced oil consumption in general, and imports from OPEC in particular. Moreover, new sources of oil have been discovered in many non-OPEC countries and prevailing world prices are conducive to continued intensive exploration. The upshot of this argument is that the quantity of oil demanded from OPEC may not increase as fast as previously expected

${ }^{2}$ For a discussion of this development, see the December 1974 issue of this Review, p. 14. even when economic growth resumes. The accruals of oil revenues by OPEC may therefore not rise, and may even decline over the next few years. Considering that OPEC imports from the oil importing countries will grow, the previously predicted accumulation of OPEC reserves is not likely to materialize. In fact, some studies taking the above factors into consideration now project OPEC balance-of-trade deficits as early as 1978. It should be pointed out that such projections do not consider the possibility of a break-up of the OPEC cartel which would result in further reduction of oil revenues.

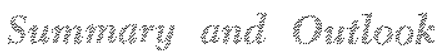

Sharply increased oil prices have significantly influenced the 1974 trade performance. Excluding petroleum imports from and general merchandise exports to OPEC, U.S. exports exceeded imports by $\$ 5$ billion. Even though U.S. merchandise exports to oil exporting countries can be expected to increase in 1975 , both the value and the volume of total agricultural exports can be expected to decline. In fact, some export orders for agricultural commodities have already been cancelled.

With respect to the emerging international economic climate, the following observations may be made. For some countries rates of inflation have already moderated, and for other countries the rates of inflation can be expected to moderate at least in the near term. For example, world commodity prices, except for food and oil, have declined since May 1973, the world food price index has declined since late November 1974, and U.S. wholesale prices have declined since December 1974. It is also likely that in the second half of 1975 real economic growth in the major industrial countries will resume.

A review of past and present economic policies lends support to the prospective developments outlined above. For example, the response of an economy to reduced monetary growth is first a slowdown in real output and subsequently a reduction in prices. At the same time, increased rates of monetary growth, which are presently being experienced in the major industrial countries, can be expected to lead to an expansion in real economic growth. If the present monetary stimulus is not too great, it is possible that the expectations of both increased real economic growth and reduced inflation may be realized.

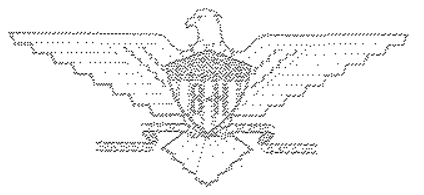

